\title{
Polyphasic evidence for the reclassification of Rhodothermus obamensis Sako et al. 1996 as a member of the species Rhodothermus marinus Alfredsson et al. 1988
}

\author{
Zélia Silva, ${ }^{1}$ Célia Horta, ${ }^{1}$ Milton S. da Costa, ${ }^{1}$ Ana Paula Chung ${ }^{1}$ \\ and Fred A. Rainey ${ }^{2}$
}

1 Centro de Neurociências de Coimbra, Departamento de Zoologia, and Departamento de Bioquímica, Universidade de Coimbra, 3000 Coimbra, Portugal

2 Department of Biological Sciences, Louisiana State University, Baton Rouge, LA 70803, USA

\author{
Author for correspondence: Milton S. da Costa. Tel: +351 2398 24024. Fax: + 351239826798 . \\ e-mail: milton@cygnus.ci.uc.pt
}

DNA-DNA reassociation studies, 165 rRNA gene sequence comparisons and fatty acid analysis were used to reassess the taxonomic status of the type strain of Rhodothermus obamensis and several strains of the genus Rhodothermus isolated from widely distributed shallow marine hot springs. The results show that the type strain of $R$. obamensis, JCM $9785^{\top}$, has a DNA-DNA reassociation value of $78 \%$ with the type strain of $R$. marinus, DSM $4252^{\top}$. The other strains examined had DNA-DNA reassociation values that varied between about 68 and $94 \%$ with $R$. marinus. The $16 S$ rRNA gene sequence was determined for the type strain of $R$. obamensis and found to share $99.5 \%$ similarity with the type strain of $R$. marinus. The fatty acid composition of $R$. obamensis was slightly different from that of the other strains examined, but indicated that this strain is very closely related to the other strains examined in this study. On the basis of DNA-DNA reassociation values, 16S rRNA gene sequence comparison and fatty acid profiles, it was concluded that $R$. obamensis and $R$. marinus represent the same species and that the name Rhodothermus obamensis should be regarded as a junior synonym of Rhodothermus marinus.

Keywords: Rhodothermus marinus, Rhodothermus obamensis, 16S rRNA gene sequence, DNA-DNA reassociation

\section{INTRODUCTION}

The first strains of the thermophilic and slightly halophilic species Rhodothermus marinus were isolated from shallow marine hot springs off the coast of Iceland by Alfredsson et al. (1988). This organism is a strictly aerobic chemo-organotroph, requiring about $0 \cdot 5-2.0 \% \mathrm{NaCl}$ for optimum growth. The optimum growth temperature is about $65-70{ }^{\circ} \mathrm{C}$ and the maximum growth temperature is around $77^{\circ} \mathrm{C}$. On the basis of $16 \mathrm{~S}$ rRNA gene sequence analysis, $R$. marinus is considered to represent a deep lineage within the Cytophaga-Flavobacterium-Bacteroides phylum, (Andrésson \& Fridjónsson, 1994).

The EMBL accession numbers for the $16 \mathrm{~S}$ rDNA sequences of strains JCM 9785', DSM 4252', DSM 4253, PRQ-34, PRQ-55, NR-29 and NR-32 are AF17493-AF17499, respectively.
Organisms similar to Rhodothermus marinus were later isolated from marine hot springs at a beach on the island of São Miguel in the Azores and from a saline hot spring about $100 \mathrm{~m}$ from the Bay of Naples at Campi Flegri, Italy (Nunes et al., 1992a, b; Moreira et al., 1996). DNA-DNA reassociation values and phenotypic characteristics indicated that these organisms belonged to the species $R$. marinus, originally isolated from Iceland, and implied that $R$. marinus had a wide distribution in saline hot springs with neutral $\mathrm{pH}$.

A new species, isolated from shallow marine hydrothermal vents in Japan and designated Rhodothermus obamensis, was described by Sako et al. (1996). The description of this species was essentially based on $16 \mathrm{~S}$ rRNA gene sequence analysis and on the higher cardinal growth temperatures of strain $\mathrm{OKD} 7^{\mathrm{T}}$. Rhodothermus obamensis was reported to have an 
optimum growth temperature of $80^{\circ} \mathrm{C}$ and a maximum growth temperature of about $85^{\circ} \mathrm{C}$ (Sako et al., 1996). The optimum growth temperature was later confirmed to be about $76^{\circ} \mathrm{C}$ (Takai et al., 1998). The extremely high growth temperature range of $R$. obamensis made it one of the most thermophilic bacteria described, which was particularly remarkable because this organism belongs to a phylum which, apart from $R$. marinus, contains only two other thermophilic species, both of the genus Thermonema, with optimum growth temperatures in the vicinity of $60{ }^{\circ} \mathrm{C}$ (Patel et al., 1994; Tenreiro et al., 1997).

During a study of the effect of the salt concentration of the medium and the growth temperature on the accumulation of compatible solutes by the type strains of $R$. marinus and $R$. obamensis, we noticed that we could not grow the latter strain above about $77^{\circ} \mathrm{C}$, irrespective of the medium used (Silva et al., 1999). This observation lead us to perform a study using representative strains of Rhodothermus originating from Iceland, the island of São Miguel, Naples, the island of Monserrat and the type strains of $R$. marinus and $R$. obamensis to assess the species status of the latter. The results of DNA-DNA reassociation and 16S rRNA gene sequence comparison indicate that all the strains, including the type strain of the species $R$. obamensis $\mathrm{OKD}^{\mathrm{T}}\left(=\mathrm{JCM} 9785^{\mathrm{T}}\right)$, belong to the species $R$. marinus.

\section{METHODS}

Strains and growth conditions. The type strain of Rhodothermus obamensis, OKD7 ${ }^{\mathrm{T}}\left(=\mathrm{JCM} 9785^{\mathrm{T}}\right)$ was obtained on two separate occasions from the Japanese Collection of Microorganisms, Riken, Japan. The first culture was obtained in December 1996 for the study on osmoadaptation and the second culture was obtained in May 1998 to confirm the identity of the first culture. The lyophilized cultures were revived using Degryse medium 162 containing $1.0 \%(\mathrm{w} / \mathrm{v})$ $\mathrm{NaCl}$ (Nunes et al., 1992b) and cultured on the same medium solidified with $2.0 \%(\mathrm{w} / \mathrm{v})$ agar at $65{ }^{\circ} \mathrm{C}$. The strains were subsequently stored at $-70{ }^{\circ} \mathrm{C}$ in the medium described above containing $15 \%$ glycerol. Rhodothermus marinus strains DSM $4252^{\mathrm{T}}$ and DSM 4253 were obtained from the DSMZ, Braunschweig, Germany. Strain RM-25 was isolated from a marine hot spring on the island of Monserrat and kindly provided by Neil Raven (CAMR, Salisbury, UK). Strains PRQ-34 and PRQ-55 were isolated from the marine hot springs at the Praia da Ribeira Quente on the island of São Miguel in the Azores (Nunes et al., 1992b); strains NR-29 and NR-32 were isolated from the Stufe di Nerone, on the Bay of Naples, Italy (Moreira et al., 1996), while strain FRR-15 was recently isolated from the marine hot spring at Ferraria on the island of São Miguel in the Azores.

16S rRNA gene sequence determination and phylogenetic analysis. The extraction of genomic DNA for 16S rRNA gene sequence determination, PCR amplification of the $16 \mathrm{~S}$ rDNA and sequencing of the purified PCR products were carried out as described previously by Rainey et al. (1996). Purified sequence reaction products were electrophoresed using a model 310 Genetic Analyzer (Applied Biosystems).
The 16S rRNA gene sequences obtained in this study were aligned against previously determined sequences available from the public databases and pairwise sequence similarity values were calculated using the ae 2 editor component of the Ribosomal Database Project (RDP-II) (Maidak et al., 1999). The accession numbers and strain designations of the $16 \mathrm{~S}$ rRNA gene sequences used as reference sequences in the comparisons are: $R$. marinus strain DSM 4252 ${ }^{\mathrm{T}}$, X80994; and $R$. obamensis strain JCM $9785^{\mathrm{T}}$, X95071.

DNA-DNA reassociation studies. DNA was extracted and purified by the procedure of Marmur (1961). The degree of DNA reassociation was determined spectrophotometrically from the initial renaturation rates, according to De Ley et al. (1970). The renaturation rates were measured in $2 \times \mathrm{SSC}$ $(1 \times \mathrm{SSC}$ is $0 \cdot 15 \mathrm{M} \mathrm{NaCl}, 0 \cdot 015 \mathrm{M}$ sodium citrate, $\mathrm{pH} 7 \cdot 0)$ using a Uvikon 940 spectrophotometer (Kontron) equipped with a thermostat-controlled cuvette chamber. The optimal renaturation temperature used in each case was calculated from the $\mathrm{G}+\mathrm{C}$ content (De Ley et al., 1970). Each hybridization experiment was executed at least twice. The published $\mathrm{G}+\mathrm{C}$ content values of Alfredsson et al. (1988) and Sako et al. (1996) were used for DNA-DNA reassociation studies.

Fatty acid analysis. Cultures for fatty acid analysis were grown on Degryse 162 medium plates, in sealed plastic bags, submerged in a water bath at $65^{\circ} \mathrm{C}$ for $24 \mathrm{~h}$. Fatty acid methyl esters (FAMEs) were obtained from fresh wet biomass by saponification, methylation and extraction as described by Kuykendall et al. (1988). The fatty acid methyl esters were separated using a Hewlett Packard model 5890 gas chromatograph equipped with a flame-ionization detector fitted with a $5 \%$ phenylmethyl silicone capillary column $(0.2 \mathrm{~mm} \times 25 \mathrm{~m}$; Hewlett Packard). The carrier gas was high-purity $\mathrm{H}_{2}$, the column head pressure was $60 \mathrm{kPa}$,

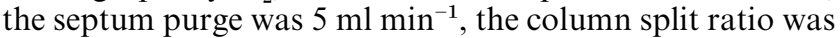
55:1 and the injection port temperature was $300^{\circ} \mathrm{C}$. The temperature of the oven was programmed from 170 to $270{ }^{\circ} \mathrm{C}$ at a rate of $5^{\circ} \mathrm{C} \mathrm{min}^{-1}$. Identification and quantification of the FAMEs, as well as the numerical analysis of the fatty acid profiles, were performed by using standard MIS Library Generation Software (Microbial ID).

\section{RESULTS AND DISCUSSION}

\section{S rRNA gene sequence comparison}

Almost complete 16S rRNA gene sequences of 1471 or $1472 \mathrm{nt}$ were determined for six Rhodothermus strains. These included the type strains of the two Rhodothermus species $R$. marinus and $R$. obamensis and four Rhodothermus strains, PRQ-34, PRQ-55, NR-29 and NR-32. Partial 16S rRNA gene sequences of $1150 \mathrm{nt}$ were determined for two additional strains, FRR-15 and RM-25. The 16S rRNA gene sequence of $R$. obamensis was determined twice. The sequences determined in this study for strain $\mathrm{JCM} 9785^{\mathrm{T}}$ were found to be identical for this strain when obtained on two separate occasions from the Japanese Collection of Microorganisms, Riken, Japan.

16S rRNA gene sequence comparisons based on a data set comprising 1502 aligned and unambiguous nucleotides between positions 38 and 1510 (Escherichia coli numbering; Brosius et al., 1978) showed all 
Table 1. 16S rRNA gene sequence similarity values for Rhodothermus strains

\begin{tabular}{|lccccccc|}
\hline Strain & $\mathbf{1}$ & $\mathbf{2}$ & $\mathbf{3}$ & $\mathbf{4}$ & $\mathbf{5}$ & $\mathbf{6}$ & $\mathbf{7}$ \\
\hline 1. R. marinus DSM $4252^{\mathrm{T}}$ & - & & & & & \\
2. R. marinus DSM 4253 & $99 \cdot 5$ & - & & & & \\
3. R. marinus PRQ-34 & $99 \cdot 2$ & $98 \cdot 9$ & - & & & \\
4. R. marinus PRQ-55 & $99 \cdot 3$ & $99 \cdot 5$ & $98 \cdot 9$ & - & & \\
5. R. marinus NR-29 & $99 \cdot 5$ & $99 \cdot 6$ & $99 \cdot 0$ & $99 \cdot 9$ & - & \\
6. R. marinus NR-32 & $99 \cdot 3$ & $99 \cdot 3$ & $99 \cdot 2$ & $99 \cdot 6$ & $99 \cdot 7$ & - & \\
7. R. obamensis JCM 9785 & $99 \cdot 5$ & $99 \cdot 5$ & $99 \cdot 1$ & $99 \cdot 5$ & $99 \cdot 7$ & $99 \cdot 7$ & - \\
\hline
\end{tabular}

Table 2. DNA-DNA reassociation values between $R$ hodothermus strains

Values are the means of at least two determinations. ND, Not determined.

\begin{tabular}{|c|c|c|c|c|c|c|c|c|c|}
\hline \multirow[t]{2}{*}{ Strain } & \multicolumn{9}{|c|}{ Degree of DNA-DNA reassociation (\%) } \\
\hline & 1 & 2 & 3 & 4 & 5 & 6 & 7 & 8 & 9 \\
\hline 1. R. marinus $\mathrm{DSM} 4252^{\mathrm{T}}$ & - & & & & & & & & \\
\hline 2. R. marinus DSM 4253 & 94 & - & & & & & & & \\
\hline 3. R. marinus PRQ-34 & 69 & 68 & - & & & & & & \\
\hline 4. R. marinus PRQ-55 & 70 & ND & 86 & - & & & & & \\
\hline 5. R. marinus NR-29 & 83 & ND & 82 & 72 & - & & & & \\
\hline 6. R. marinus NR-32 & 81 & ND & 77 & 96 & 79 & - & & & \\
\hline 7. R. marinus FRR-15 & 78 & ND & 89 & 92 & 89 & 89 & - & & \\
\hline 8. R. marinus RM-25 & 81 & 78 & 91 & 90 & 96 & 86 & 78 & - & \\
\hline 9. R. obamensis JCM $9785^{\mathrm{T}}$ & 78 & ND & 71 & 78 & 84 & 70 & 84 & 81 & - \\
\hline
\end{tabular}

sequences determined in this study to have 98.999.9\% similarity (Table 1 ). $16 \mathrm{~S}$ rRNA gene sequence similarities between strains PRQ-34, PRQ-55, NR-29 and NR-32 were 98.9-99.9\%; these strains shared sequence similarities to the type strain of $R$. marinus DSM $4252^{\mathrm{T}}$ of $99 \cdot 2-99 \cdot 5 \%$. The two partial $16 \mathrm{~S}$ rRNA gene sequences $(\sim 1150 \mathrm{nt})$ determined for strains FRR-15 and RM-25 have 98.8-100\% similarity to the other sequences determined in this study. The $16 \mathrm{~S}$ rRNA gene sequence of the previously described $R$. marinus strain DSM 4253 was shown to have $99 \cdot 5 \%$ similarity to DSM $4252^{\mathrm{T}}$ and $98.9-99.6 \%$ similarity to the other strains. Sequence similarity of $99.9 \%$ was found between the 16S rRNA gene sequence for the $R$. marinus type strain determined in this study and the sequence available from the public databases under the accession number X80994. The 16S rRNA gene sequence of $R$. obamensis strain JCM $9785^{\mathrm{T}}$ determined in this study shared only $97 \cdot 2 \%$ similarity with the previously determined sequence of the same strain available from the public databases under the accession number X95071. This newly determined sequence of strain JCM $9785^{\mathrm{T}}$ had $99.5 \%$ similarity to the $16 \mathrm{~S}$ rRNA gene sequence of the type strain of $R$. marinus and similarities in the range $99 \cdot 1-99 \cdot 7 \%$ to the other Rhodothermus strains used in this study. These data demonstrate a high level of $16 \mathrm{~S}$ rRNA sequence similarity ( $>98.9 \%$ ) between all strains having similar characteristics to the two species of the genus Rhodothermus. There is a clear difference $(2 \cdot 8 \%)$ between the previously determined 16S rRNA gene sequence of $R$. obamensis (X95071) and that determined in this study. Close examination of the sequence deposited under accession number X95071 by alignment with other 16S rRNA gene sequences shows that it includes additional nucleotides (which may be attributed to automated base calling errors) not found within the other members of the domain Bacteria and a number of clearly erroneous nucleotides.

\section{DNA-DNA reassociation data}

These data demonstrate a high level of relatedness (68-96\%) between the Rhodothermus strains for which DNA-DNA reassociation values were determined (Table 2). The results show that strain JCM $9785^{\mathrm{T}}$ had a DNA-DNA reassociation value of $78 \%$ with the type strain of Rhodothermus marinus and values in the range $70-84 \%$ with the other strains studied, indicating that these strains are closely related (Table 2). Moreover, all other strains examined had high DNADNA reassociation values with each other and with the type strain of $R$. marinus. The lowest DNA-DNA reassociation values of 68 and $69 \%$ were observed 
Table 3. Fatty acid composition of Rhodothermus strains grown at $65^{\circ} \mathrm{C}$

Values are the means of two determinations. Values below $0.5 \%$ were not considered. Abbreviations: i, iso; a, anteiso; n, straight chain.

\begin{tabular}{|c|c|c|c|c|c|c|c|c|c|c|c|}
\hline \multirow[t]{2}{*}{ Strain* } & \multicolumn{11}{|c|}{ Fatty acid composition (\% of the total) } \\
\hline & iC14 & nC14 & iC15 & aC15 & iC16 & nC16 & iC17 & aC17 & iC18 & nC18 & aC19 \\
\hline R. marinus DSM $4252^{\mathrm{T}}$ & $1 \cdot 4$ & - & $8 \cdot 1$ & $20 \cdot 0$ & $11 \cdot 4$ & $6 \cdot 1$ & $25 \cdot 3$ & $19 \cdot 9$ & $5 \cdot 1$ & - & - \\
\hline R. marinus DSM 4253 & $0 \cdot 9$ & - & $6 \cdot 6$ & $21 \cdot 6$ & $7 \cdot 6$ & $6 \cdot 3$ & $24 \cdot 3$ & $26 \cdot 1$ & $3 \cdot 5$ & $1 \cdot 1$ & $0 \cdot 6$ \\
\hline R. marinus PRQ-34 & $0 \cdot 9$ & - & $9 \cdot 1$ & $15 \cdot 2$ & $9 \cdot 7$ & $5 \cdot 8$ & $30 \cdot 2$ & $20 \cdot 5$ & $4 \cdot 8$ & $1 \cdot 3$ & $0 \cdot 9$ \\
\hline R. marinus PRQ-55 & $0 \cdot 5$ & - & $9 \cdot 1$ & $23 \cdot 6$ & $9 \cdot 0$ & $6 \cdot 1$ & $30 \cdot 0$ & $23 \cdot 2$ & $1 \cdot 1$ & $0 \cdot 7$ & - \\
\hline R. marinus NR-29 & - & - & $9 \cdot 1$ & $21 \cdot 9$ & $2 \cdot 9$ & $1 \cdot 9$ & $30 \cdot 3$ & $20 \cdot 1$ & $1 \cdot 0$ & $1 \cdot 4$ & - \\
\hline R. marinus NR-32 & - & - & $8 \cdot 7$ & $23 \cdot 5$ & $2 \cdot 2$ & $9 \cdot 0$ & $30 \cdot 6$ & $22 \cdot 1$ & $0 \cdot 8$ & $1 \cdot 3$ & - \\
\hline R. marinus FRR-15 & - & $0 \cdot 6$ & $12 \cdot 2$ & $22 \cdot 7$ & $4 \cdot 0$ & $10 \cdot 8$ & $29 \cdot 2$ & $17 \cdot 3$ & $0 \cdot 8$ & $0 \cdot 8$ & - \\
\hline R. marinus $\mathrm{RM}-25$ & $0 \cdot 6$ & - & $8 \cdot 8$ & $23 \cdot 0$ & $6 \cdot 5$ & $6 \cdot 0$ & $29 \cdot 3$ & $22 \cdot 7$ & $1 \cdot 5$ & - & - \\
\hline R. obamensis JCM 9785 & - & - & $12 \cdot 3$ & $19 \cdot 4$ & $3 \cdot 6$ & $3 \cdot 4$ & $41 \cdot 0$ & $17 \cdot 3$ & $1 \cdot 2$ & - & - \\
\hline
\end{tabular}

between strains PRQ-34, strain DSM 4253 and the type strain of $R$. marinus. However, these strains lack distinctive phenotypic characteristics (Nunes et al., 1992a) and the DNA-DNA reassociation values obtained are within the range proposed for the definition of a bacterial species (Wayne et al., 1987). On the basis of the DNA-DNA reassociation values obtained, all of the strains examined in this study, including $R$. obamensis strain JCM $9785^{\mathrm{T}}$, can be considered strains of a single species, namely $R$. marinus.

\section{Fatty acid composition}

The fatty acid composition of strains of $R$. marinus has been difficult to reproduce in replicate determinations because of the erratic growth of some of the organisms on solid media (Nunes et al., 1992b; Moreira et al., 1996; our unpublished results). To minimize this difficulty, all strains were grown in duplicate on the same batch of medium. The results show that the fatty acid composition of $R$. obamensis is slightly different from the other strains examined. In this organism the odd-chain/even-chain branched fatty acid ratio is higher than in the other organisms (Table 3). However, highly variable fatty acid compositions are known to occur in strains belonging to the same species. A very large variation in the fatty acid composition is found, for example, among the strains of the species of Thermus thermophilus that share very high DNADNA reassociation values (Manaia et al., 1994; Nobre et al., 1996). In the case of $R$. obamensis the fatty acid composition, although slightly different from the other strains examined in this study, is in congruence with the results that show all the strains examined to be genetically closely related.

\section{Optimum growth temperature}

The cardinal growth temperatures of all microorganisms are influenced by the composition of the medium. In the study on the accumulation of com- patible solutes by the type strains of the two Rhodothermus species, we utilized medium MJ, used in the description of $R$. obamensis, in parallel with modified medium 162 to grow $R$. marinus (Silva et al., 1999). The results show that strain JCM $9785^{\mathrm{T}}$ was not more thermophilic than $R$. marinus and, if anything, had a slightly lower maximum growth temperature in both media. However, strain JCM $9785^{\mathrm{T}}$ had a slightly different $\mathrm{NaCl}$ requirement than the type strain of $R$. marinus, which had already been observed by Sako et al. (1996). The differences in the optimum growth temperature obtained by Sako et al. (1996) and by Silva et al. (1999) may be due to slightly different growth conditions and we may not have been able to completely reproduce the original growth conditions. Nevertheless, strains JCM $9785^{\mathrm{T}}$ and the type strain of $R$. marinus were always grown in parallel on the same batch of medium.

It is sometimes not possible to compare all the type strains of genera with numerous species when a new species of that genus is characterized. We recommend that type strains of as many species as possible, especially those known to be closely related to the new isolates be used to confirm and to compare the characteristics of new isolates, with those that have been previously reported, to reveal possible differences in characteristics due to modifications of methodologies used in different laboratories. In the case of the genus Rhodothermus, only one species had been described and it would have been useful to use it as a control. The failure to use the type strain, and perhaps the reference strain of $R$. marinus, may have resulted in the assertion that strain $\mathrm{JCM} 9785^{\mathrm{T}}$ had higher cardinal growth temperatures. Strain JCM $9785^{\mathrm{T}}$ may have higher growth temperatures than those reported by Silva et al. (1999), because medium MJ could not be exactly reproduced or because of differences in other growth parameters, but it is almost certain that the cardinal growth temperatures of strain JCM $9785^{\mathrm{T}}$ will not be very different from those of $R$. marinus. 


\section{Taxonomic conclusions}

On the basis of the DNA-DNA reassociation values, which are well within the limits proposed for the definition of a bacterial species (Wayne et al., 1987), the high level of $16 \mathrm{~S}$ rDNA sequence similarity and the highly similar fatty acid profiles, we propose that strain JCM $9785^{\mathrm{T}}\left(=\mathrm{OKD}^{\mathrm{T}}\right)$ belongs to the species $R$. marinus and that the name $R$. obamensis should be regarded as a junior synonym of the name $R$. marinus.

\section{ACKNOWLEDGEMENTS}

This work was supported, in part by the PRAXIS XXI Program (PRAXIS/PCNA/BIO/46/96), Portugal. We thank Niel Raven (CAMR, Salisbury, UK) for the gift of strain RM-25.

\section{REFERENCES}

Alfredsson, G. A., Kristjánsson, J. K., Hjörleifsdottir, S. \& Stetter, K. O. (1988). Rhodothermus marinus, gen. nov., sp. nov., a thermophilic, halophilic bacterium from submarine hot springs in Iceland. J Gen Microbiol 134, 299-306.

Andrésson, O. S. \& Fridjónsson, O. H. (1994). The sequence of the single 16S rRNA gene of the thermophilic eubacterium Rhodothermus marinus reveals a distant relationship to the group containing Flexibacter, Bacteroides, and Cytophaga species. $J$ Bacteriol 176, 6165-6169.

Brosius, J., Palmer, M. L., Kennedy, P. J. \& Noller, H. F. (1978). Complete nucleotide sequence of a $16 \mathrm{~S}$ ribosomal RNA gene from Escherichia coli. Proc Natl Acad Sci USA 75, 4801-4805.

De Ley, J., Cattoir, H. \& Reynaerts, A. (1970). The quantitative measurement of DNA hybridization from renaturation rates. Eur J Biochem 12, 133-142.

Kuykendall, L. D., Roy, M. A., O’Neill, J. J. \& Devine, T. E. (1988). Fatty acids, antibiotic resistance, and deoxyribonucleic acid homology groups of Bradyrhizobium japonicum. Int J Syst Bacteriol 38, 358-361.

Maidak, B. L., Cole, J. R., Parker, C. T., Jr \& 11 other authors (1999). A new version of the RDP (Ribosomal Database Project). Nucleic Acids Res 27, 171-173.

Manaia, C. M., Hoste, B., Gutierrez, M. C., Gillis, M., Ventosa, A., Kersters, K. \& da Costa, M. S. (1994). Halotolerant Thermus strains from marine and terrestrial hot springs belong to Thermus thermophilus (ex Oshima \& Imahori, 1974) nom. rev. emend. Syst Appl Microbiol 17, 526-532.
Marmur, J. (1961). A procedure for the isolation of deoxyribonucleic acid from micro-organisms. J Mol Biol 3, 208-218.

Moreira, L., Nobre, M. F., Sá-Correia, I. \& da Costa, M. S. (1996). Genomic typing and fatty acid composition of Rhodothermus marinus. Syst Appl Microbiol 19, 83-90.

Nobre, M. F., Carreto, L., Wait, R., Tenreiro, S., Fernandes, O., Sharp, R. J. \& da Costa, M. S. (1996). Fatty acid composition of the species of the genera Thermus and Meiothermus. Syst Appl Microbiol 19, 303-311.

Nunes, O. C., Donato, M. M., Manaia, C. M. \& da Costa, M. S. (1992a). The polar lipid and fatty acid composition of Rhodothermus strains. Syst Appl Microbiol 15, 59-62.

Nunes, O. C., Donato, M. M. \& da Costa, M. S. (1992b). Isolation and characterization of Rhodothermus strains from S. Miguel, Azores. Syst Appl Microbiol 15, 92-97.

Patel, B. K. C., Saul, D. S., Reeves, R. A., Williams, L. C., Cavanagh, J.-E., Nichols, P. D. \& Bergquist, P. L. (1994). Phylogeny and lipid composition of Thermonema lapsum, a thermophilic gliding bacterium. FEMS Microbiol Lett 115, 313-318.

Rainey, F. A., Ward-Rainey, N., Kroppenstedt, R. M. \& Stackebrandt, E. (1996). The genus Nocardiopsis represents a phylogenetically coherent taxon and a distinct actinomycete lineage: proposal of Nocardiopsaceae fam. nov. Int J Syst Bacteriol 46, 1088-1092.

Sako, Y., Takai, K., Ishida, Y., Uchida, A. \& Katayama, Y. (1996). Rhodothermus obamensis sp. nov., a modern lineage of extremely thermophilic marine bacteria. Int J Syst Bacteriol 46, 1099-1104.

Silva, Z., Borges, N., Martins, L. O., Wait, R., da Costa, M. S. \& Santos, H. (1999). Combined effect of the growth temperature and salinity of the medium on the accumulation of compatible solutes by Rhodothermus marinus and Rhodothermus obamensis. Extremophiles 3, 163-172.

Takai, K., Nunoura, T., Sako, Y. \& Uchida, A. (1998). Acquired thermotolerance and temperature-induced protein accumulation in extremely thermophilic bacterium Rhodothermus obamensis. J Bacteriol 180, 2770-2774.

Tenreiro, S., Nobre, M. F., Rainey, F. A., Miguel, C. \& da Costa, M. S. (1997). Thermonema rossianum sp. nov., a new thermophilic and slightly halophilic species from saline hot springs in Naples, Italy. Int J Syst Bacteriol 47, 122-126.

Wayne, L. G., Brenner, D. J., Colwell, R. R. \& 9 other authors (1987). International Committee on Systematic Bacteriology. Report of the ad hoc committee on reconciliation of approaches to bacterial systematics. Int J Syst Bacteriol 37, 463-464. 